Brazilian Journal

of Chemical

ISSN 0104-6632

Printed in Brazil

Engineering

www.scielo.br/bjce

Vol. 35, No. 03, pp. 969-976, July - September, 2018

dx.doi.org/10.1590/0104-6632.20180353s20170528

\title{
STATISTICAL OPTIMIZATION OF ETTRINGITE PRECIPITATION IN LANDFILL LEACHATE
}

\author{
Ahmet Aygun ${ }^{1, *}$, Selim Dogan ${ }^{2}$ and Mehmet Emin Argun ${ }^{2}$ \\ ${ }^{1}$ Bursa Technical University, Faculty of Engineering and Natural Sciences, Department of \\ Environmental Engineering, 16109 Bursa, Turkey \\ ${ }^{2}$ Konya Technical University, Faculty of Natural Sciences and Engineering, Department of \\ Environmental Engineering, 42003 Konya, Turkey
}

(Submitted: October 18, 2017; Revised: January 14, 2018; Accepted: January 15, 2018)

\begin{abstract}
In the present study, experiments were conducted to optimize sulfate removal efficiency with ettringite precipitation from landfill leachate using Response Surface Methodology (RSM) and Central Composite Design (CCD). The statistical analysis of the results showed that the operating parameters such as molar rates of $\mathrm{Ca} /$ $\mathrm{SO}_{4}$ and $\mathrm{Al} / \mathrm{SO}_{4}$, and $\mathrm{pH}$ had a significant effect on sulfate removal efficiency. Aluminum hydroxide and calcium hydroxide were used for external sources of aluminum and calcium. The goodness of the model was checked by different criteria including the coefficient of determination $\left(\mathrm{R}^{2}=0.94\right), p$ value $(<0.0001)$, adequate precision (14.78), and coefficient of variance (7.30). The RSM results indicated that the fitted model could be appropriate to predict sulfate removal efficiency. A 55.7\% maximum sulfate removal efficiency was obtained at $\mathrm{pH} 11.95$ for $2.29 \mathrm{Ca} / \mathrm{SO}_{4}$ and $0.74 \mathrm{Al} / \mathrm{SO}_{4}$ molar ratios. Sulfate inhibition effects on treatment methods such as the anaerobic process decreased with increasing $\mathrm{COD} / \mathrm{SO}_{4}$ ratio from 14:1 to $25: 1$ by ettringite precipitation.
\end{abstract}

Keywords: Ettringite Precipitation, Landfill, Leachate, Response Surface Methodology (RSM), Sulphate Removal

\section{INTRODUCTION}

Municipal solid waste management is one of the major environmental problems for the cities in the world. Landfills are commonly a cost-efficient way to dispose of municipal solid waste. One of the important environmental problems in landfills is production of leachate having high organic and inorganic contents such as sulfate $\left(\mathrm{SO}_{4}^{2-}\right)$ and sulfide $\left(\mathrm{S}^{2-}\right)$, ammonium $\left(\mathrm{NH}_{4}^{+}\right)$, phosphate $\left(\mathrm{PO}_{4}^{3-}\right)$, heavy metals, and chloride (Talalaj, 2015).

There are no common methods offered for treatment of leachate produced from landfills. However, one of the biological, physical (air stripping and adsorption), and chemical treatment methods (coagulation, flocculation and chemical oxidation) or their combination can be used (Agdag and Sponza,
2005; Aygun et al., 2012; Campagna et al., 2013; Derco et al., 2010; Ilhan et al., 2008; Trebouet et al., 2001; Yilmaz et al., 2010).

Leachate composition mainly depends on the age of the landfill, as well as the waste type and hydrogeological factors (de Morais and Zamora, 2005). Leachates classified as young, middleaged, and mature need to be treated in a proper way (Sari et al., 2013).

Biological treatment methods such as aerobic, anaerobic, and anoxic processes are usually applied for young landfill leachate due to its high organic content, which are highly desirable for biodegradation. But, inhibitory compounds such as sulphate affect both anaerobic biodegradation of high organic content in leachate and treatment performance (Percheron et al., 1997). Excess amount of sulphate will promote

*Corresponding author. E-mail address: ahmet.aygun@btu.edu.tr 
enhanced growth of sulfate-reducing bacteria, which compete with methane bacteria, resulting in a decrease of methane production (Fang et al., 1997). Yilmaz et al. (2012) investigated the effects of $\mathrm{COD} / \mathrm{SO}_{4}$ ratio up to 20:1 on anaerobic process performance. Their study showed that the performance sharply increased when the $\mathrm{COD} / \mathrm{SO}_{4}$ ratio ranged from $4: 1$ to $10: 1$.

Ettringite precipitation based on formation of sulphate salts with low solubility can be used as a pretreatment method to overcome sulfate inhibition in anaerobic process. Calcium alumina-sulfate is commonly used to identify ettringite mineral. The following equation shows the basic chemical reaction to form ettringite $\mathrm{Eq}(1)$ :

$$
\begin{aligned}
& 6 \mathrm{Ca}^{2+}+3 \mathrm{SO}_{4}^{2-}+2 \mathrm{Al}(\mathrm{OH})_{4^{-}}+4 \mathrm{OH}^{-}+26 \mathrm{H}_{2} \mathrm{O} \rightarrow \\
& 3 \mathrm{CaO} . \mathrm{Al}_{2} \mathrm{O}_{3} .3 \mathrm{CaSO}_{4} .32 \mathrm{H}_{2} \mathrm{O}_{(s)}
\end{aligned}
$$

Ettringite precipitation can be applied for removal of sulfate from textile wastewater (Tunay et al., 2014), acidic mine drainage (Madzivire et al., 2010), tap water (Woroszynska et al., 1996) and as well as heavy metals removal from aqueous phases (Zhang and Reardon, 2003).

Response Surface Methodology (RSM) is widely accepted as a statistic-based method for designing experiments, evaluating the individual and interaction effects of independent variables, and optimizing the process parameters with a limited number of experimental runs (Sudamalla et al., 2012).

RSM provides predicted experimental data which might have an effect on the response using predetermined ranges of the independent variables. Thereafter, experimental data are used as input for the model optimization. Some major outcomes of RSM optimization are used to estimate the coefficients, predict the responses and examine an adequacy of the mathematical model.

The purpose of the current study is to investigate optimum conditions for high sulfate $\left(\mathrm{SO}_{4}{ }^{2-}\right)$ removal from landfill leachate by using an ettringite precipitation process. As a result of a literature review, no scientific work has been published dealing with the application of RSM to ettringite precipitation in landfill leachate. The most widely used form of RSM, Central Composite Design (CCD), was applied by using Design Expert software to determine the interactions of important process variables such as $\mathrm{Ca} / \mathrm{SO}_{4}$ and $\mathrm{Al} /$ $\mathrm{SO}_{4}$ molar rates, and $\mathrm{pH}$ on the sulfate $\left(\mathrm{SO}_{4}{ }^{2-}\right)$ removal efficiency.

\section{MATERIALS AND METHODS}

\section{Leachate sampling and analytical methods}

Konya with a population of 2 million is located in the central part of Turkey. Leachate samples were collected from the active detention pond in a municipal landfill site of Konya. The leachate samples taken from the active detention pond, which is less than 5 years old (classified as young landfill leachate), were stored in plastic bottles and kept in $4{ }^{\circ} \mathrm{C}$ until the required analysis. Characterization of leachate is given in Table 1.

\begin{tabular}{lcc}
\multicolumn{3}{l}{ Table 1. Characterization of raw leachate. } \\
\hline Parameter & Unit & Value \\
\hline $\mathrm{pH}$ & - & 7.77 \\
$\mathrm{COD}$ & $\mathrm{mg} / \mathrm{L}$ & 27545 \\
$\mathrm{BOD}$ & $\mathrm{mg} / \mathrm{L}$ & 17500 \\
$\mathrm{SO}_{4}^{-2}$ & $\mathrm{mg} / \mathrm{L}$ & 1965 \\
$\mathrm{PO}_{4}^{-}-\mathrm{P}$ & $\mathrm{mg} / \mathrm{L}$ & 23.3 \\
$\mathrm{NH}_{4}^{-} \mathrm{N}$ & $\mathrm{mg} / \mathrm{L}$ & 3890 \\
\hline
\end{tabular}

Batch experiments were conducted in a jar test apparatus for the following minutes and rpms; $5 \mathrm{~min}$ at $120 \mathrm{rpm}, 20 \mathrm{~min}$ at $45 \mathrm{rpm}$ and finally $30 \mathrm{~min}$ for settling. $\mathrm{pH}$ was adjusted with either $6 \mathrm{M} \mathrm{HCl}$ or $\mathrm{NaOH}$.

All chemicals used in this research were analytical grade supplied by Merck. $\mathrm{COD}, \mathrm{BOD}_{5}$, Sulfate, Phosphate-phosphorus, Ammonium-nitrogen, and $\mathrm{pH}$ were analyzed based upon Standard Methods (APHA et al. 2012).

\section{Experimental design and data analysis}

The Design Expert Software (version 8.0.7.1) was used for the statistical design of experiments and data analysis. In this study, CCD and RSM were applied to optimize the three most important operating variables, which are $\mathrm{pH}$ and molar ratios of $\mathrm{Ca} / \mathrm{SO}_{4}$ and $\mathrm{Al} / \mathrm{SO}_{4}$.

In the present work, CCD with three replicates at the center point was used to find the relationship between the response function and variables (Table 2). A total of 17 experiments were conducted. $\mathrm{Ca} / \mathrm{SO}_{4}$ molar ratios $(\mathrm{A}), \mathrm{Al} / \mathrm{SO}_{4}$ molar ratios $(\mathrm{B})$, and $\mathrm{pH}(\mathrm{C})$ were set at five coded value levels: -1.68 (minimum), $-1,0$ (central), +1 , and +1.68 (maximum).

Ettringite precipitation was performed to optimize sulfate removal for predetermined $\mathrm{Ca}: \mathrm{SO}_{4}: \mathrm{Al}$ molar ratios that ranged from $(0.32: 1.00: 0.11)$ to (3.68:1.00:1.21), and $\mathrm{pH}$ values from 9.32 to 12.68 , 
Table 2. Experimental range and levels of the independent variables used in RSM

\begin{tabular}{lcccc}
\hline $\begin{array}{l}\text { Independent process } \\
\text { variables code }\end{array}$ & -1.68 & \multicolumn{3}{c}{ Real values of coded levels } \\
\cline { 2 - 5 } & 0.32 & -1 & 0 & 1 \\
\hline $\mathrm{A}: \mathrm{Ca} / \mathrm{SO}_{4}$ molar ratios & 0.11 & 0.33 & 2 & 3.68 \\
$\mathrm{~B}: \mathrm{Al} / \mathrm{SO}_{4}$ molar ratios & 9.32 & 10 & 0.66 & 0.99 \\
$\mathrm{C}: \mathrm{pH}$ & & 1.21 & 12 \\
\hline
\end{tabular}

respectively. Aluminum hydroxide and calcium hydroxide were used to form ettringite minerals.

RSM postulates the functional relationship between the controllable input parameters and the obtained response surfaces. The lowest-order polynomial was chosen to adequately describe the sulfate removal. For evaluation of experimental data, the response variable was fitted by a second-order quadratic polynomial model as follows Eq (2):

$y=\beta_{0}+\sum_{i=1}^{k} \beta_{i} X_{i}+\sum_{i=1}^{k} \beta_{i i} X_{i}^{2}+$

$\sum_{i=1}^{k-1} \sum_{j=2}^{k} \beta_{i j} X_{i} X_{j}+\varepsilon$

where $i$ is the linear coefficient, $j$ is the quadratic coefficient, $\beta$ is the regression coefficient, $k$ is the number of factors studied and optimized in the experiment and $\varepsilon$ is the random error. The analysis focused on verifying the influence of individual parameters on the percentage of sulfate removal. The actual design parameters of experiments and their responses as sulfate removal efficiency for ettringite precipitation are given in Table 3.

The method of least squares was used to best fit a model equation by minimizing the residual error. The calculated coefficients for the model equation were tested for statistical significance. Stepwise elimination method and the $p$-values criterion were used to improve the reliability of the RSM model and also to automatically reduce the terms that are not significant.

Analysis of variance (ANOVA), known as a model independent probabilistic sensitivity analysis method, was used to obtain the interaction between the process variables and the response. Based on the ANOVA data, the fitted polynomial model was checked for coefficient of determination $R^{2}$, predicted $\mathrm{R}^{2}$, adjusted $\mathrm{R}^{2}$ and Fisher's $F$-test value and by the $p$-value (probability) of model terms with $95 \%$ confidence level. Three-dimensional plots and their respective contour plots were obtained for sulfate removal based on the three factors at five levels of $\mathrm{Ca} / \mathrm{SO}_{4}$ and $\mathrm{Al} / \mathrm{SO}_{4}$ molar ratios and $\mathrm{pH}$.
Table 3. The actual design parameters of ettringite precipitation and sulfate removal efficiencies.

\begin{tabular}{ccccc}
\hline Exp No & $\mathrm{Ca} / \mathrm{SO}_{4}\left(\mathrm{x}_{1}\right)$ & ${\mathrm{Al} / \mathrm{SO}_{4}\left(\mathrm{x}_{2}\right)}$ & $\mathrm{pH}\left(\mathrm{x}_{3}\right)$ & $\begin{array}{c}\text { Sulfate } \\
\text { removal } \\
(\%)\end{array}$ \\
\hline 1 & 3.00 & 0.99 & 10.00 & 45.0 \\
2 & 2.00 & 0.66 & 12.68 & 55.6 \\
3 & 3.00 & 0.33 & 10.00 & 30.3 \\
4 & 2.00 & 0.66 & 11.00 & 52.2 \\
5 & 2.00 & 0.66 & 11.00 & 52.2 \\
6 & 2.00 & 1.21 & 11.00 & 39.4 \\
7 & 2.00 & 0.66 & 9.32 & 32.0 \\
8 & 1.00 & 0.33 & 12.00 & 44.0 \\
9 & 1.00 & 0.99 & 10.00 & 34.9 \\
10 & 2.00 & 0.11 & 11.00 & 20.6 \\
11 & 3.00 & 0.33 & 12.00 & 37.7 \\
12 & 3.00 & 0.99 & 12.00 & 50.2 \\
13 & 1.00 & 0.99 & 12.00 & 45.5 \\
14 & 0.32 & 0.66 & 11.00 & 35.9 \\
15 & 2.00 & 0.66 & 11.00 & 52.2 \\
16 & 3.68 & 0.66 & 11.00 & 45.0 \\
17 & 1.00 & 0.33 & 10.00 & 35.4 \\
\hline
\end{tabular}

\section{RESULTS AND DISCUSSION}

\section{Statistical Analysis}

Traditional optimization methods are not sufficient to express the combined effects of all operating parameters (Ozer et al., 2009). Therefore, RSM was used to optimize each parameter in order to determine the combined effects of all inputs. RSM and CCD experimental design were employed to determine the single and combined effects of $\mathrm{Ca} / \mathrm{SO}_{4}$ and $\mathrm{Al} / \mathrm{SO}_{4}$ molar ratios and $\mathrm{pH}$ on sulfate removal efficiency. The optimization process involved three steps; (1) performing the statistically designed experiments, (2) estimating coefficients of the proposed model and predicting the response of the process, and (3) checking the validity of the model (Rao and Satyanarayana, 2003). 
Experimental data was analyzed by using the RSM procedure. Significant model terms are sought to obtain a good fit of the model. For evaluation of experimental data, the response variable was fitted by a second-order quadratic polynomial model. The final mathematical model equation was obtained by using Design Expert software as follows in terms of actual factors $\operatorname{Eq}(3)$ :

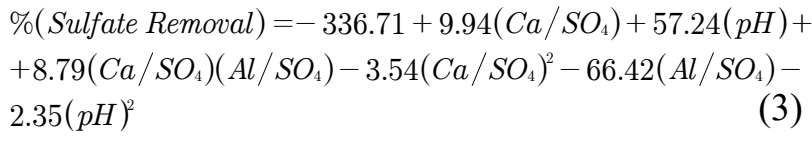

Table 4 shows that the model to predict sulfate removal was significant at the $5 \%$ confidence level since the $p$ value was less than 0.05 . Fisher's F-test is used to compute both $p$ and the lack of fit (LOF) values that describe the variation of the data around the fitted model. If the model does not fit the data well, this LOF is significant when the LOF value is smaller than 0.05 . Both insignificant LOF and significant $p$ values indicate good correlation between the process variables and the response. A high $\mathrm{R}^{2}$ coefficient is desirable and it ensures a good fit of the second-order quadratic model to the experimental data (Ghafari et al., 2009). The adjusted $\mathrm{R}^{2}$ value is particularly useful when comparing models with different numbers of model terms. This comparison is, however, done in the background when model reduction is taking place. The differences between the predicted $\mathrm{R}^{2}$ and the adjusted $\mathrm{R}^{2}$ was 0.16 . The model fitted the data and can reliably be used to interpolate because the difference was less than 0.2 (Nair et al., 2014).

A low value $(7.30 \%)$ of the coefficient of variance $(\mathrm{CV})$, which is similar to previously published data, indicates a high degree of precision of the experimental values (Yusuf et al., 2013). Adequate Precision (AP), calculated as 14.78 for the signal-to-noise ratio for the fitted model, was higher than 4 , indicating an adequate model discrimination (Rahbar and Haji, 2013).

The Predicted Residual Sums of Squares (PRESS) statistic gives a good indication of the predictive power of the fitted model and minimizing of PRESS is desirable. In our study, the PRESS value of the obtained second-order quadratic model is smaller than those of the linear, two-factor interactions (2FI), and cubic equations.
Actual values were obtained from experimental runs, and the predicted values were evaluated from the model and generated by using the approximating functions. The actual and the predicted sulfate removal efficiency is shown in Figure 1. The plot indicates an adequate agreement between actual and predicted data. As a result, the predicted model is reliable and can be used to navigate the design space defined by the CCD.

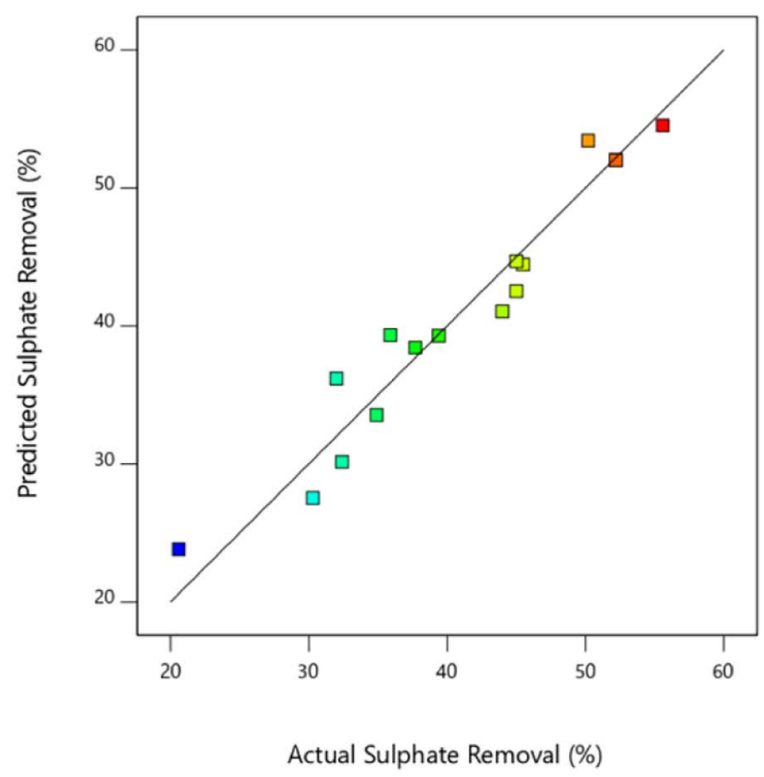

Figure 1. The actual versus the predicted sulfate removal efficiency.

Figures 2, 3 and 4 show the response surface contour plots of the second-order quadratic model with one variable kept at the central level and the other two variables within the experimental ranges. Different surfaces can be obtained by adjusting the constant variable.

Figure 2 shows the response surface obtained at constant $\mathrm{pH}$ of 11.00. It is clearly seen in Figure 2 that the effects of $\mathrm{Ca} / \mathrm{SO}_{4}$ and $\mathrm{Al} / \mathrm{SO}_{4}$ molar ratios were significant on sulfate removal efficiency. Maximum sulfate removal efficiency was observed at the central point of the plot. However, sulfate removal efficiency by ettringite precipitation sharply decreased at either the highest or lowest molar ratios of $\mathrm{Ca} / \mathrm{SO}_{4}$ and $\mathrm{Al} /$ $\mathrm{SO}_{4}$ values.

When $\mathrm{pH}$ value and $\mathrm{Ca} / \mathrm{SO}_{4}$ molar ratio are compared to each other for sulfate removal efficiency

Table 4. ANOVA results for response parameters.

\begin{tabular}{lccccccccc}
\hline Response & $\boldsymbol{p}$ & LOF & $\boldsymbol{R}^{2}$ & $\operatorname{AdjR}^{2}$ & $\operatorname{PrdR}^{2}$ & AP & S.D. & CV & PRESS \\
\hline $\begin{array}{l}\text { Sulfate } \\
\text { Removal }\end{array}$ & $<0.001$ & 0.345 & 0.94 & 0.90 & 0.74 & 14.78 & 3.03 & 7.30 & 389.6 \\
\hline
\end{tabular}




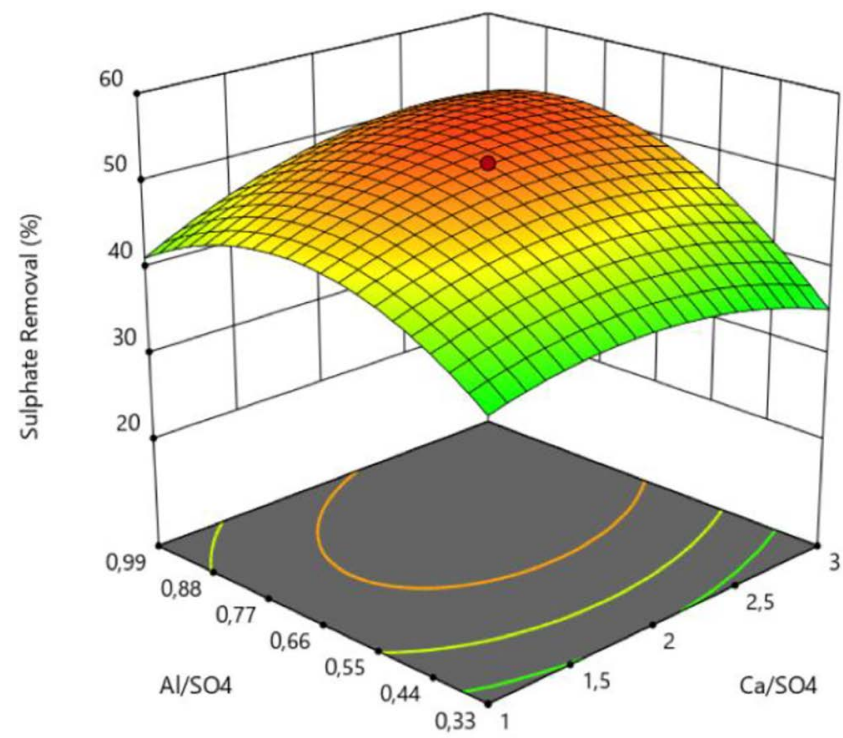

Figure 2. The effect of $\mathrm{Ca} / \mathrm{SO}_{4}$ and $\mathrm{Al} / \mathrm{SO}_{4}$ molar ratios on sulfate removal (pH: 11.00).

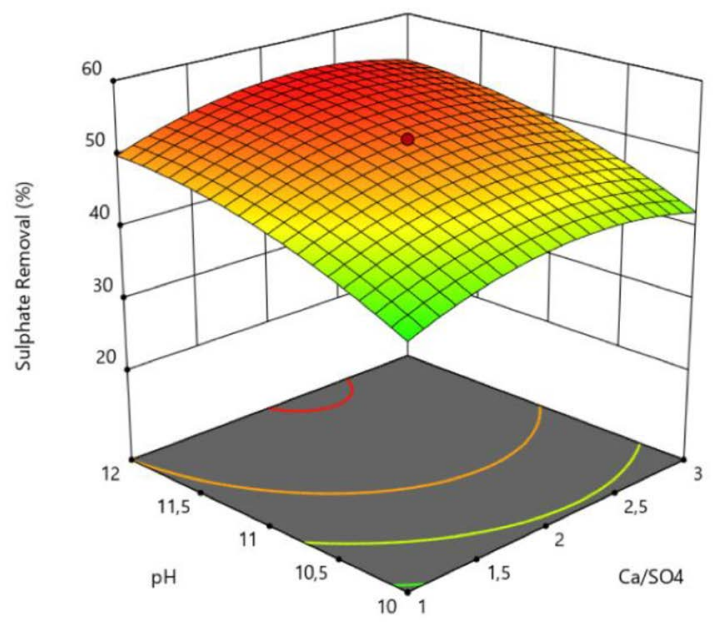

Figure 3. The effect of $\mathrm{Ca} / \mathrm{SO}_{4}$ molar ratio and $\mathrm{pH}$ on sulfate removal $\left(\mathrm{Al} / \mathrm{SO}_{4}: 0.66\right)$.

at constant molar ratio of $0.66 \mathrm{Al} / \mathrm{SO}_{4}$, the effects of $\mathrm{pH}$ changes on sulfate removal efficiency are greater than that of the $\mathrm{Ca} / \mathrm{SO}_{4}$ ratio. For $\mathrm{pH} 10.00$ and $\mathrm{Ca} / \mathrm{SO}_{4}$ molar ratio of 1.00 , sulfate removal efficiency reached $35 \%$, which is the minimum value given in Figure 3 .

In Figure 4, sulfate removal efficiency ranged from $30 \%$ to $55 \%$ for different $\mathrm{pH}$ and $\mathrm{Al} / \mathrm{SO}_{4}$ molar ratios. Minimum removal efficiency was observed at $\mathrm{pH} 10.00$ and $0.33 \mathrm{Al} / \mathrm{SO}_{4}$ molar ratio. Higher $\mathrm{pH}$ values and $\mathrm{Al} / \mathrm{SO}_{4}$ ratios increased the sulfate removal efficiency. $\mathrm{Al} / \mathrm{SO}_{4}$ molar ratio was a more influential parameter compared with $\mathrm{pH}$.

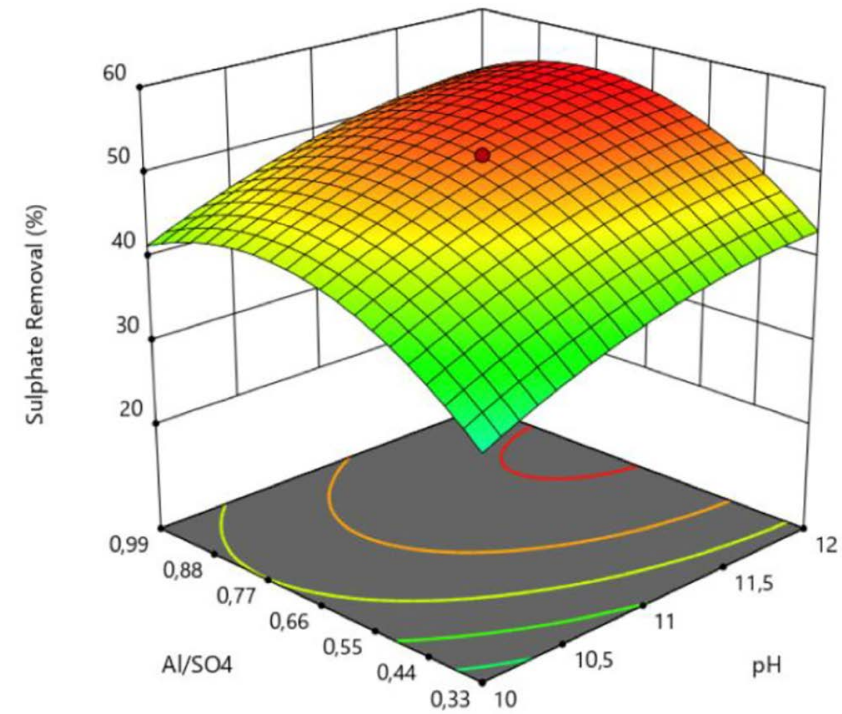

Figure 4. The effect of $\mathrm{Al} / \mathrm{SO}_{4}$ molar ratio and $\mathrm{pH}$ on sulfate removal $\left(\mathrm{Ca} / \mathrm{SO}_{4}: 2.00\right)$.

\section{Optimization of the process parameters and verification}

Numerical optimization tools of RSM can be used to find the best solution for maximum removal efficiency by using independent variables such as $\mathrm{pH}$, molar ratio of $\mathrm{Ca} / \mathrm{SO}_{4}$ and $\mathrm{Al} / \mathrm{SO}_{4}$ selected to be within the study range. Selection constraints for each parameter are given in Table 5.

Based on optimization results, maximum sulfate removal efficiency was estimated as $55.7 \%$ at $\mathrm{pH}$ $11.95,2.29 \mathrm{Ca} / \mathrm{SO}_{4}$ and $0.74 \mathrm{Al} / \mathrm{SO}_{4}$ molar ratios. The desirability function value was found to be 1.00 , showing that our model could be successfully applied to experimental data.

A $\mathrm{pH}$ of 12 previously published for sulfate removal using an ettringite precipitation process in textile wastewater is similar to the optimum $\mathrm{pH}$ value estimated in this study. The ratios of each reagent were found a little bit higher than the stoichiometric ratio (Kabdasli et al., 2016).

Verification experiment was performed with the predicted conditions for maximum sulfate removal efficiency. The experimental value $(55.8 \%)$ was very close to the predicted value $(55.7 \%)$, confirming the validity of the fitted models. These results confirm that the model can be used for sulfate removal efficiency.

\section{Evaluation of $\mathrm{COD} / \mathrm{SO}_{4}$ ratio}

Methane production in anaerobic processes can be dramatically affected by the ratio of $\mathrm{COD} / \mathrm{SO}_{4}$. During the ettringite precipitation process, sulfate 
Table 5. Selection constraints for each parameter in the optimization.

\begin{tabular}{lcccc}
\hline Parameter & Goal & $\begin{array}{c}\text { Lower } \\
\text { Limit }\end{array}$ & $\begin{array}{c}\text { Upper } \\
\text { limit }\end{array}$ & Importance \\
\hline $\mathrm{Ca} / \mathrm{SO}_{4}$ molar ratio & In range & 1 & 3 & 3 \\
$\mathrm{Al} / \mathrm{SO}_{4}$ molar ratio & In range & 0.33 & 0.99 & 3 \\
$\mathrm{pH}$ & In range & 10 & 12 & 3 \\
$\begin{array}{l}\text { Response } \\
(\% \text { sulfate removal) }\end{array}$ & Maximize & 20.6 & 55.6 & 3 \\
\hline
\end{tabular}

concentration decreased from $1965 \mathrm{mg} / \mathrm{L}$ to $870 \mathrm{mg} / \mathrm{L}$, but COD removal efficiency was only around $20 \%$. Raw leachate had a $\mathrm{COD} / \mathrm{SO}_{4}$ ratio of $14: 1$ which was slightly above 10:1, the termination level of methane production (Parkin et al., 1990; Percheron et al., 1997; Vavilin et al., 1994). A high ratio of $\mathrm{COD} / \mathrm{SO}_{4}$ such as 20:1 was found to minimize the inhibition effect on anaerobic methane production (Yilmaz et al., 2012).

Ettringite precipitation increased the ratio of COD/ $\mathrm{SO}_{4}$ from $14: 1$ to $25: 1$, which was above the required ratio. This result supports that ettringite precipitation may be used as pretreatment of landfill leachate to improve methane production and to decrease corrosion in cogeneration units.

\section{CONCLUSIONS}

The present study corroborates the benefit of RSM over traditional methods to optimize process conditions for sulfate removal efficiency from landfill leachate. A $55.7 \%$ maximum sulfate removal efficiency was obtained at $\mathrm{pH} 11.95$ for $2.29 \mathrm{Ca} / \mathrm{SO}_{4}$ and $0.74 \mathrm{Al} / \mathrm{SO}_{4}$ molar ratios. The CCD and RSM were used to develop a reasonable mathematical model for prediction of the optimum process conditions for ettringite precipitation. Increasing the $\mathrm{COD} / \mathrm{SO}_{4}$ ratio from $14: 1$ to $25: 1$ resulted in less sulfate inhibition on anaerobic methane production. The cost-effective approaches for sulfate removal can be derived from optimized $\mathrm{Ca} / \mathrm{SO}_{4}$ and $\mathrm{Al} / \mathrm{SO}_{4}$ molar ratios in $\mathrm{RSM}$. The ratios of each reagent were found to be a little bit higher than the stoichiometric ratio.

\section{ACKNOWLEDGEMENTS}

This study was carried out as pre-experiments of project funded by the The Scientific and Technological Research Council of Turkey, TUBITAK (Grant No.: 115Y031). The authors would like to thank to Huseyin Saglam for pre-experimental data.

\section{REFERENCES}

Agdag, O.N., Sponza, D.T., Anaerobic/aerobic treatment of municipal landfill leachate in sequential two-stage up-flow anaerobic sludge blanket reactor (uasb)/completely stirred tank reactor (CSTR) systems. Process Biochem., 40, 895-902 (2005).

APHA, AWWA, WPCF Standard methods for the examination of water and wastewater. American Water Works Assn., Washington (2012).

Aygun, A., Yilmaz, T., Nas, B., Berktay, A., Effect of temperature on fenton oxidation of young landfill leachate: Kinetic assessment and sludge properties. Global Nest J., 14, 487-495 (2012).

Campagna, M,Cakmakci, M. Yaman, F.B., Ozkaya, B., Molecular weight distribution of a full-scale landfill leachate treatment by membrane bioreactor and nanofiltration membrane, Waste Manag., 33(4), 866-870 (2013).

de Morais, J.L., Zamora, P.P., Use of advanced oxidation processes to improve the biodegradability of mature landfill leachates. J. Hazard Mater., 123, 181-186 (2005).

Derco, J,Gotvajn, A.Z., Zagorc-Koncan, J.,Almasiova, B., Kassai, A., Pretreatment of landfill leachate by chemical oxidation processes. Chem. Pap., 64, 237-245 (2010)

Fang, H.H.P., Liu, Y., Chen, T., Effect of sulfate on anaerobic degradation of benzoate in UASB reactors. J Environ Eng-Asce, 123, 320-328 (1997).

Ghafari, S., Aziz, H.A., Isa M.H.,Zinatizadeh, A.A., Application of response surface methodology (rsm) to optimize, coagulation-flocculation treatment of leachate using poly-aluminum chloride (pac) and alum. J. Hazard Mater., 163, 650-656 (2009).

Ilhan, F., Kurt, U., Apaydin, O., Gonullu, M.T., Treatment of leachate by electrocoagulation using aluminum and iron electrodes. J. Hazard Mater., 154, 381-389 (2008).

Kabdasli, I., Bilgin, A., Tunay, O., Sulphate control by ettringite precipitation in textile industry wastewaters. Environ Technol., 37, 446-451 (2016).

Madzivire, G., Petrik, L.F., Gitari, W.M., Ojumu, T.V., Balfour, G. Application of coal fly ash to circumneutral mine waters for the removal of sulphates as gypsum and ettringite. Miner. Eng., 23, 252-257 (2010).

Nair, A.T., Makwana, A.R., Ahammed, M.M., The use of response surface methodology for modelling and analysis of water and wastewater treatment processes: a review. Water Sci. Technol., 69(3), 464-478 (2014).

Ozer, A., Gurbuz, G., Calimli, A., Korbahti, B.K., Biosorption of copper(II) ions on enteromorpha prolifera: Application of response surface 
methodology (RSM). Chem. Eng. J., 146, 377-387 (2009).

Parkin, G.F., Lynch, N.A., Kuo, W.C., Vankeuren, E.L., Bhattacharya, S.K., Interaction between sulfate reducers and methanogens fed acetate and propionate. Res. J. Water Pollut. Contr, Fed., 62, 780-788 (1990).

Percheron, G., Bernet, N., Moletta, R., Start-up of anaerobic digestion of sulfate wastewater. Bioresource Technol., 61, 21-27 (1997).

Rahbar, R.S., Haji, A., Use of d-optimal design to model and the analysis of the effect of the draw ratio on some physical properties of hot multistage drawn nylon 6 fibers. J. Appl. Polym. Sci., 130, 1337-1344 (2013).

Rao, J.L.U.M., Satyanarayana, T., Statistical optimization of a high maltose-forming, hyperthermostable and $\mathrm{Ca}^{2+}$-independent alphaamylase production by an extreme thermophile geobacillus thermoleovorans using response surface methodology. J .Appl. Microbiol., 95, 712718 (2003).

Sari, H., Yetilmezsoy, K., Ilhan, F., Yazici, S., Kurt, U., Apaydin, O., Fuzzy-logic modeling of Fenton's $\mathrm{b}$ chemical oxidation process treating three types of landfill leachates. Environ. Sci. Pollut. Res., 20(6), 4235-4253 (2013).

Sudamalla, P., Pichiah, S., Manickam, M., Responses of surface modeling and optimization of brilliant green adsorption by adsorbent prepared from citrus limetta peel. Desalin. Water Treat., 50, 367-375 (2012).

Talalaj, I.A., Mineral and organic compounds in leachate from landfill with concentrate recirculation, Environ. Sci. Pollut. Res. Int., 22(4), 2622-2633 (2015).

Trebouet, D., Schlumpf, J.P., Jaouen, P., Quemeneur, F. Stabilized landfill leachate treatment by combined physicochemical-nanofiltration processes. Water Res., 35, 2935-2942 (2001).

Tunay, O., Simseker, M., Olmez-Hanci, T., Kabdasli, I., Sulphate removal from indigo dyeing wastewaters by ettringite precipitation. Fresen. Environ. Bull., 23, 3405-3409 (2014).

Vavilin, V.A., Vasiliev, V.B., Rytov, S.V., Ponomarev, A.V., Self-oscillating coexistence of methanogens and sulfate-reducers under hydrogen-sulfide inhibition and the ph-regulating effect. Bioresource Technol., 49, 105-119 (1994).

Woroszynska, A., VanLeuven, K., Wilms, D., Removal of sulphates from tap water by precipitation or crystallization of ettryngite. Environ. Sci. Res., 51, 193-201(1996).

Yilmaz, T., Aygun, A., Berktay, A., Nas, B., Removal of cod and colour from young municipal landfill leachate by fenton process. Environ. Technol., 31, 1635-1640 (2010).

Yilmaz, T., Erdirencelebi, D., Berktay, A., Effect of $\mathrm{COD} / \mathrm{SO}_{4}{ }^{2-}$ ratio on anaerobic treatment of landfill leachate during the start-up period. Environ. Technol., 33, 313-320 (2012).

Yusuf, F., Chaubey, A., Raina, A., Jamwal, U., Parshad, R., Enhancing nitrilase production from fusarium proliferatum using response surface methodology. Springerplus, 2:290 (2013).

Zhang, M., Reardon, E.J., Removal of B, Cr, Mo, and $\mathrm{Se}$ from wastewater by incorporation into hydrocalumite and ettringite. Environ. Sci. Technol., 37, 2947-2952 (2003). 
